\title{
Situated learning in translator and interpreter training: Model United Nations simulations
}

\author{
Gökçen Hastürkoğlu a * \\ ${ }^{a}$ Atılım University, Ankara, Turkey \\ APA Citation:
}

Hastürkoğlu, G. (2019). The Situated learning in translator and interpreter training: Model United Nations simulations. Journal of Language and Linguistic Studies, 15(3), 914-925.

Submission Date: 11/03/2019

Acceptance Date: $26 / 07 / 2019$

\begin{abstract}
The necessity of incorporating both theory and practice in translation an interpretation pedagogy has always been emphasized by trainers at translation and interpretation departments. Situated learning activities, as most scholars agree, are environments where students can achieve deep learning by putting theory into practice. The view presented in this paper is that the Model United Nations (MUN) simulation, a situated learning environment, can profitably be applied in undergraduate translator and interpreter pedagogy and help students' achieve deep learning mainly across the meta-cognitive knowledge domain. The data was gathered from the surveys of the outcomes pertaining to the spring terms in the academic years 2015-2016, 2016-2017, and 2017-2018 as well as the forms sent to students via university's student information system by which they could evaluate and comment on the course, the trainer, and their own performances. The results of the assessments were further consolidated with two quizzes conducted each term in which the students were tested about the related terminologies and the debated topics. The results demonstrate strong metacognitive development among learners, deep learning achieved through the active participation in the simulations, and students' being provided with the required knowledge and skills for their future careers.
\end{abstract}

(C) 2019 JLLS and the Authors - Published by JLLS.

Keywords: Translator training; translation and interpretation; situated learning activity; deep learning; Model United Nations simulation; translation pedagogy

\section{Introduction}

The mission of the undergraduate programmes of translation and interpretation departments at universities is to train professionals who are eager to do research and contribute to the advancement of knowledge, are in interaction with related disciplines, are interested in current issues and cultural relations, are aware of the expectations and requirements of the market, stay in cooperation with the industry, market, and community, and can adopt the latest physical and technological resources in translation and interpretation. Thus, trainers in undergraduate translation and interpretation departments aim to enhance students' translation competence through preparing programmes which include both theoretical and applied translation courses. In these courses, trainers take into account the fact that the competence of the translator lies in having a wide range of world knowledge and theoretical information

\footnotetext{
* Corresponding author. Tel.: +90 5303055152

E-mail address: gokcen.hasturkoglu@atilim.edu.tr
} 
and also multi-faceted skills such as linguistic, technological, professional, social, cultural, and metacognitive, the last of which has many sub-competences and "plays a decisive role in enhancing the translation quality and efficiency" (Yanqun, 2015, p. 70). According to Yanqun, "metacognition is what translators need to satisfy the demands of the age, to meet the requirement of translation in the current context, and a powerful weapon that translators must develop to fulfill communicative tasks" (2015, p.70).

As most scholars agree, metacognition is one of the most crucial factors students must have in order to succeed. Among the environments in which students of translation and interpretation can develop their metacognitive skills, situated learning activities have been proved to be very influential in order to provide them with the professional competences they require for nearly ten years.

The last decade has witnessed an increasing number of studies focusing on the importance of situated learning approaches in translation and interpretation pedagogy (Risku, 2002; Kiraly, 2000, 2005). They all support student-centred and research-based approaches rather than traditional methods, which are abstracted from the context of use. Kiraly (2000), for instance, states in his introductory chapter that knowledge is no longer provided to students by teachers, but it is students who create knowledge. It has been discussed that it is mainly in these simulation-driven teaching environment that students achieve deep learning. In this respect, Anderson and Krathwohl (2001) describe four levels of knowledge in this process: factual knowledge, which is described as the key element students must know to effectively solve problems in a particular field; conceptual knowledge, which is students' understanding of the web of relationships among ideas; procedural knowledge, defined as knowing how to do things; and metacognitive knowledge, which is described as students' awareness of their learning. Students tend to develop their factual, conceptual, procedural, and metacognitive knowledge through situated learning activities applied during courses.

As one of the situated learning methods, Model United Nations (MUN) simulations, which can briefly be defined as an academic simulation of the United Nations, have been a key tool to facilitate deep learning requiring the active involvement of students and including learning at the metacognitive level. In these settings, students are required to act as delegates or ambassadors of the UN member countries which they are assigned to, and provide solutions to the issues raised.

Previous studies have mainly focused on the applicability of the MUN in the field of international relations, such as Fortin's (2012) measurement of how simulation based learning, specifically the MUN, can have an impact on the academic achievement of students studying at the department of international relations by making a comparison between conventional course structures and the simulation-based course structure. Similarly, Engel's study (2017) supports incorporating the MUN facilitated deep learning and gaining professional skills in the field of international relations. However, there has not been any research conducted to evaluate the effects of such simulations in translation and interpretation classes. Despite the high number of studies proving the importance of situated learning in the training of students studying at the departments of translation and interpretation, such as by role-playings, mock conferences, or simulations (Prieto-Velasco and Fuentes-Luque 2016; Li 2015; Calvo 2015), there has not been any study specifically delving into the merits of the MUN simulations in the undergraduate translation and interpretation education and how they have an effect on students' deep learning.

Thus, this paper is an attempt to shed light on the development of translation and interpretation pedagogy by supporting the importance and benefits of integrating MUN simulations into undergraduate translation and interpretation curriculum. To this end, we apply two types of course evaluations conducted at a university, Turkey: the Learning Outcomes Surveys and the forms completed in the Student Information System for the spring terms of 2015-2016, 2016-2017, and 2017-2018. These two sources helped the researcher assess the students' metacognitive level of knowledge achieved through 
MUN simulations. Furthermore, the results of two quizzes conducted each spring term throughout the stated academic year where the students were asked about the meanings of related terminologies as well as other topics debated were included in the analysis of this study.

\subsection{Theoretical background}

\subsubsection{Deep Learning and Metacognition}

Deep learning, as opposed to surface learning, can be described as one "that takes root in our apparatus of understanding, in the embedded meanings that define us and that we use to define the world" (Tagg, 2003, p. 70). In other words, it requires to understand the underlying meanings, rather than the surface meanings, and to apply the theoretical knowledge gathered to real life.

While providing students the opportunity to better retain information and create connections to other areas, deep learning gives instructors the chance 'to adjust instruction to meet students' needs: what is appropriate and why; effective implementation, organization, and planning; re-teaching, enrichment and extensions; instructing and demonstrating; providing feedback; questioning and problem solving; thus enhancing the learning paradigm" (Pearson \& Harvey, 2013, p. 61).

The deep learning process can mostly be achieved in environments where students have the opportunity to involve themselves within their own learning by using metacognitive strategies. The importance of metacognition has been emphasized in learning, as there is evidence that students' academic success is directly related to their metacognitive abilities (Adey \& Shayer, 1993; Schraw, 1998; Kuhn \& Pearsall, 1998; Veenman, Prins, \& Elshout, 2002).

In his 1976 article, Flavell, who is most often associated with the term 'metacognition', defined metacognition as follows: "In any kind of cognitive transaction with the human or non-human environment, a variety of information processing activities may go on. Metacognition refers, among other things, to the active monitoring and consequent regulation and orchestration of these processes in relation to the cognitive objects or data on which they bear, usually in service of some concrete goal or objective" (p. 232). Similarly, according to Senemoğlu (2007, p. 336) metacognition is "generally the knowledge of one's own cognitive system, its structure, its functioning; in other words, the awareness of one's own cognitive structure and the learning characteristics and the ability to monitor and regulate one's own cognitive processes." As inferred, metacognition is related to monitoring, regulating, and controlling one's own processes such as thinking, problem solving, comprehending, reasoning, memory and learning.

In order to learn new information, students have to go through metacognitive realization, which means that they have to be aware of the differences among their previous and current thoughts about the topic (qtd. in Yanqun, 2015, p. 72). Through metacognitive experiences, students can find out which strategy is more effective in order to fulfill the objectives related to a certain learning unit and "metacognitive knowledge is confirmed when the defined objectives are achieved as a result of the activity" (Altındağ \& Senemoğlu, 2013, p. 16). As Zull also pointed out, "the ultimate outcome of the journey [from brain toward mind] is to understand your own understanding" (2011, p. 15), it is very important for students to improve their metacognitive skills in order to achieve deep learning and become successful.

\subsubsection{Situated Learning Environments: The Case of MUN}

One of the most effective approaches in which deep learning can be achieved by students is the use of situated learning methods such as simulations. On the benefits of situated learning methods, it can be agreed that "situated learning environments offer contexts in which students find an opportunity to work on authentic activities and learn how to transfer knowledge to real-life situations" (qtd. in Prieto-Velasco 
\& Fuentes Luque, 2016, p. 78). Relatedly enough, according to Stein (1998), a situated learning experience has four main factors that guide the classroom activities:

(1) learning is grounded in the actions of everyday situations; (2) knowledge is acquired situationally and transfers only to similar situations; (3) learning is the result of a social process encompassing ways of thinking, perceiving, problem solving, and interacting in addition to declarative and procedural knowledge; and (4) learning is not separated from the world of action but exists in robust, complex, social environments made up of actors, actions, and situations. (p. 1)

The quotation above is in line with the approaches on the situated learning methods which situated cognitionists prefer to use. As Hendricks (2001) highlights, when students are exposed to abstract instruction which is bound to the context it occurs in, they cannot apply it in the real-world as what they learn cannot be generalized to the real-world situations (p. 303). On the contrary, in a situated learning environment, students have the chance to become producers of knowledge which helps ensuring deep learning.

MUN can establish an environment where students can actively participate in the ongoing processes in courses and achieve deep learning. It has been practiced by over 400.000 students all over the world and can be defined as a role-playing simulation in which 'real-life' United Nations takes place and international political issues are discussed and debated. As Hazleton and Mahurin (1986) also stressed in their study, the MUN is a "learning laboratory" that increases "cognitive knowledge of diplomatic strategies and outcomes; enhance understanding of key concepts and the complexities of the situations being simulated; and reinforce, change and/or develop participant attitudes toward the objects of the simulation" (p. 151).

Before the sessions, students have to do search about their assigned countries and also gain information on the topic to be debated. Each time they are required to act as the ambassadors of a different country and to dwell on the issues from the perspective of that specific country. During the sessions, students present opening speeches and position papers they have written, negotiate with other students, and read aloud the resolution they prepare at the end of the debate in accordance with the UN rules and procedures followed in actual settings. Furthermore, during the simulations, they use formal language, and public speaking, active listening skills, and note-taking skills.

By taking into account the merits of applying MUN in the courses, the present study aimed to demonstrate how these simulations can be adapted and applied in translation and interpretation departments and reveal the benefits associated with this approach for future translators and interpreters.

\section{Method}

\subsection{Participants}

The Learning Outcomes Surveys, course evaluation forms, and two quizzes were provided to a total of 55 sophomore students who had registered in ETI206 International Politics course in the spring terms of the 2015-2016, 2016-2017, and 2017-2018 at the Department of Translation and Interpretation of a university in Turkey.

\subsection{Application}

The simulations of MUN were conducted within the framework of the ETI206 International Politics course for which the students met once on a weekly basis and in three-hour sessions. In the first week, the students were acquainted with the course through the syllabus, and the course objectives were 
presented to them entailing studies on the topics of international politics with a view to increase their knowledge of world affairs and develop their language and translational skills. The topics to be debated were provided to them beforehand, such as 'access to medication in the context of pandemics like HIV/AIDS', 'protection of migrants and their families, promotion of the realization of the right to drinking water and sanitation', 'combatting internet cyber-bullying and privacy infringements', 'promotion of the enjoyment of the cultural rights of everyone and respect for different cultural identities', etc., all of which appear on the UN agenda along many other topics. What is more, the related preparation studies and the sources the students could refer to while investigating the issues were presented in the syllabus.

Two weeks were allocated for the instruction on the structure of the United Nations, the functioning of the UN and its bodies, information on the MUN such as the reason behind its application all over the world, language used in debates, rules for writing opening speeches, policy statements, resolutions, voting procedures, etc. Furthermore, video recordings of the MUN simulations from different parts of the world were displayed in class so as to further familiarize the students with such debates in actual settings. Then, assignments for the following weeks' simulations were provided. Each week, a major topic from the world agenda was chosen by the instructor for in-class simulation. One student was designated as the chair of the MUN, and the rest as the ambassadors to different UN countries with one week of preparation time to learn about the assigned countries, search about the position and attitude of their countries towards the issue to be debated, and prepare their opening speeches and policy statements accordingly. The students were also required to prepare glossaries on the issue. All the opening speeches, position papers and glossaries were posted on Moodle, a learning management system, until the deadline in order for the instructor to write a feedback for each student.

During the simulations, each student delivered an opening speech including highlights related to the issue and, then, a more detailed position paper. The delegate whose country was announced was required to deliver a speech in accordance to the rules of public speaking. Other students were to take notes in order to ask questions to the delegate. This necessity was thought to help the students develop their notetaking skills which are required for ETI311 Note-Taking course offered in the third-year. After all delegates finished reading their position papers, they started to prepare a resolution, which is a formal document including all the proposed solutions to the issue and is written with a special format consisting of a heading, a pre-ambulatory clause, and an operative clause. After the resolution was brought to the floor by the main submitter, it was voted upon. When the debate was closed, the students were divided into groups according to class size and were asked to translate the resolution from English into Turkish. This translation was later examined and related feedback was provided to each group. This activity was considered to be beneficial for the courses of ETI409 Translation of Texts on Law and International Affairs and ETI412 European Union Studies and Translation, both of which are fourth-year courses. All sessions were video-recorded for future reflection and students' self-assessments.

The knowledge the students gained on the debate issues as well as the related terminology was assessed using two quizzes. This was with due consideration that gaining the knowledge of current issues occupying the world agenda and vocabulary from a variety of areas are important for trainee translators and interpreters in their upcoming courses and future careers.

\subsection{Instruments}

The first instrument used for testing the contribution of the MUN simulations within the scope of the ETI206 International Politics course was the Learning Outcomes Survey designed by the instructor of that course for the past five years. The survey was intended to evaluate whether the students had mastered the related skills upon the completion of the courses. 
The response scale (5-point Likert scale) for the Learning Outcomes Survey was as the following:

5. (Strongly Agree): achieved up to a very high extent

4. (Agree): achieved to a high extent

3. (Neutral): achieved to some extent

2. (Disagree): achieved to a small extent

1. (Strongly Disagree): not achieved

This response scale was interpreted as the following:

- A combination of 5 (strongly agree) and 4 (agree) in three tables would mean: 'highly achieved' by the students.

- 3 (neutral) would mean: 'partly achieved' by the students.

- A combination of 2 (disagree) and 1 (strongly disagree) would mean: 'not achieved' by the students.

There were five questions in the Learning Outcomes Survey as appears below:

a) To what extent did you develop your skills to search for specific issues within the field of international politics?

b) To what extent did you develop your skills for oral and written communication on the issues of international politics both in Turkish and English?

c) To what extent did you acquire the terminology of issues discussed within the field of international politics?

d) To what extent did you learn about presenting in front of formal audience by using formal language?

e) To what extent did you learn about the approaches for translating texts on international politics?

The five skills targeted by these questions and to be rated were strongly emphasized in the course syllabus and discussed throughout each term the course was given.

The second instrument was the Course Evaluation Form completed at the end of each academic term and for each course through the Student Information System (SIS) which is an online programme for the evaluation of courses and lecturers at the University. In this way, information was elicited from students in the form of open-ended questions, in which they could use their own words to comment on the course and the lecturer. For this study, the opinions of the students on the effectiveness of the MUN simulations and the students' own learning processes were gathered through this form, and were later grouped as either benefits or drawbacks.

Moreover, the data gathered from the Learning Outcomes Survey and the Course Evaluation Forms was strengthened with the results of two quizzes conducted each term in which the students were asked the meanings of related terminologies provided in each debate and two content-based open-ended questions on the topics debated during the simulations (such as the consequences of migration, measures that can be taken for human rights violations caused by cultural pressure, governments' responsibilities for combatting internet cyber bullying and privacy infringements, etc.). The average scores of the students in each quiz appear in percentages in this study. 


\section{Results and Discussion}

The analysis of data is undertaken in three sections. The results of the Learning Outcomes Survey are provided in separate tables for three academic years (Table 1, Table 2, Table 3).

The results of the course evaluation forms are presented in one table (Table 4) for the 2017-2018, 2016-2017 and 2015-2016 academic years. Table 4 demonstrates the number of students who commented in the same way and shared the same ideas, followed by a random selection of quotes.

Finally, Table 5 presents the average scores of the two quizzes conducted each term for the stated academic years in the ETI206 International Politics course.

\subsection{Results of Learning Outcomes Survey}

The results of the Learning Outcomes Survey conducted in the 2017-2018 Spring term are demonstrated in Table 1, followed by Table 2 for 2016-2017, and Table 3 for 2015-2016.

Table 1. 2017-2018 Spring term survey assessment

\begin{tabular}{|c|c|c|c|c|c|}
\hline & Strongly Agree & Agree & Neutral & Disagree & $\begin{array}{l}\text { Strongly } \\
\text { Disagree }\end{array}$ \\
\hline Question 1 & 16 & 0 & & & \\
\hline Question 2 & 15 & 1 & & & \\
\hline Question 3 & 16 & 0 & & & \\
\hline Question 4 & 14 & 2 & & & \\
\hline Question 5 & 16 & 0 & & & \\
\hline Total & 77 & 3 & & & \\
\hline Percentage & $96.25 \%$ & $3.75 \%$ & & & \\
\hline
\end{tabular}

Number of students answered the survey: 16

Table 2. 2016-2017 Spring term survey assessment

\begin{tabular}{llcccc}
\hline & Strongly Agree & Agree & Neutral & Disagree & $\begin{array}{c}\text { Strongly } \\
\text { Disagree }\end{array}$ \\
\hline Question 1 & 22 & 2 & & \\
Question 2 & 21 & 3 & & \\
Question 3 & 23 & 1 & & \\
Question 4 & 24 & 0 & & \\
Question 5 & 24 & 0 & & \\
Total & 114 & 6 & & \\
Percentage & $95 \%$ & $5 \%$ & & \\
\hline
\end{tabular}

Number of students answered the survey: 24 
Table 3. 2015-2016 Spring term survey assessment

\begin{tabular}{llcccc}
\hline & Strongly Agree & Agree & Neutral & Disagree & $\begin{array}{c}\text { Strongly } \\
\text { Disagree }\end{array}$ \\
\hline Question 1 & 10 & 5 & & \\
Question 2 & 11 & 4 & & \\
Question 3 & 9 & 6 & & \\
Question 4 & 10 & 5 & & \\
Question 5 & 13 & 2 & & \\
Total & 53 & 22 & & \\
Percentage & $70.66 \%$ & $29.33 \%$ & & \\
\hline
\end{tabular}

Number of students answered the survey: 15

As it can be clearly observed from the tables, the percentage of those who were very satisfied with the application of these situated learning activities in the course is $100 \%$. They all agreed that, at the end of the MUN simulations, they had developed their skills of research, oral and written communication both in Turkish and English, acquired the related terminologies in international politics, learned how to make formal presentations, and also learned about the approaches for translating texts on international politics.

\subsection{Results of Course Evaluation Forms}

Table 4 contains the results of the course evaluation forms, which were anonymously filled by the students in 2017-2018, 2016-2017, 2015-2016 academic years, pointing to the benefits and drawbacks of the MUN simulations.

Table 4. Course evaluation form results for the 2017-2018, 2016-2017, 2015-2016 academic years

\begin{tabular}{llc}
\hline Benefits and Drawbacks & \# of Students \\
\hline Acquisition of terminology & 41 \\
Development of research skills & 34 \\
Increasing world knowledge & 27 \\
Development of speaking skills & 19 \\
Coping with stress & 17 \\
& Development of writing skills & 16 \\
& Real-life experience & 16 \\
& Learning translation of Texts on & 15 \\
Law & \\
& Preparation for the future courses & 14 \\
& Development of note-taking skills & 11 \\
Having chance to self-evaluation & \\
Limited time for preparation & 8 \\
& \\
\hline
\end{tabular}


As illustrated in Table 4, the most prominent advantage of the MUN was the acquisition of terminology. Fourty-one students shared the view that they had learned terminologies on a variety of issues such as economy, environment, health, politics, culture, etc. One of the related comments reads as follows: "I would like to thank the instructor for giving me the chance to learn such broad terminology, with which I can create a dictionary on international relations."

In this study, similar comments on the acquisition of terminologies make it clear that the MUN simulations are suitable settings to learn terminologies in various fields and to apply them in proper contexts.

Another skill targeted by the simulations was the development of research skills also applied by the students by searching about their designated countries, the issues to be debated, and previously written UN resolutions on the issues. On this subject, one comment was: "With these simulations, I realized that I did not know how to do proper research and sort out the relevant and required information prior to this course."

The contribution of the MUN in gaining world knowledge, which is required for translators and interpreters, was also emphasized by the 27 students in the course evaluation forms. One comment was: "Thanks to this course, and the terminology [that it offers], I learned about countries and [also learned that] I had to be interested in world issues about which I had never heard before."

According to Table 4, there were students who also emphasized that the simulations developed their speaking, writing, and note-taking skills; helped them cope with stress by providing them with real-life experiences and preparing them for their future courses. Students also added that the simulations gave them chance to evaluate themselves, thereby improving their metacognitive skills.

On the other hand, the only drawback of the course suggested by only one of the student is the limited time for preparation. This student stated that one week was not enough for research on the countries, the issues to be debated, preparing the terminology, writing the opening speech and the position paper. Even though this disadvantage may be overcome by extending the sessions' time limit from 3 hours to 6 hours (in two weeks), such an application may reduce the momentum of the simulations and the interest of the students. For this reason, the author believes that no change should be made in this respect.

\subsection{Quiz Results}

Table 5 demonstrates the results of the quizzes, each of which includes two content-based openended questions (50 points) and fifty terminologies (50 points) related to the issues debated.

Tablo 5. Quiz results averages

\begin{tabular}{lcc}
\hline Academic Term & $\begin{array}{c}\text { Average score } \\
\text { of Quiz 1 }\end{array}$ & $\begin{array}{c}\text { Average score of } \\
\text { Quiz 2 }\end{array}$ \\
\hline $2017-2018$ & 92,6 & 91,4 \\
$2016-2017$ & 90,8 & 93 \\
$2015-2016$ & 96,8 & 92,6 \\
\hline
\end{tabular}

As presented in Table 5, the average scores of the quizzes reveal the fact that the students achieved to a very high extend the required knowledge of the issues debated as well as the terminologies provided during the simulations. 


\section{Conclusions}

It is agreed that translators and interpreters have to assume many roles during their professional lives such as researchers, terminologists, cultural transmitters, linguists, editors, and authors. They are required to be fluent in verbal and written communication and need to have an acceptable degree of knowledge related to world affairs. Bearing their roles and qualifications in mind, training of translators and interpreters in undergraduate programmes and preparing them for their future careers should be conducted within a multi-faceted approach more effectively. One such settings is situated learning environments, through which students tend to develop their meta-cognitive skills, and can achieve deep learning in their educational lives.

By taking all these into consideration, this study intends to demonstrate the benefits of one such environment, the MUN simulations, and their design principles and procedures. To do so, the study assesses the students' metacognitive knowledge with the help of two evaluation methods, a survey and an evaluation form, and also reaffirms how they achieve deep learning using two quizzes conducted in the course.

The initial analysis of the data indicates that integrating MUN simulations into the ETI206 International Politics course is very beneficial for students, who can experience actual settings, gain a fair knowledge of the tactics of teamwork cooperation and labour division, learn a variety of terminologies related to world affairs, improve their research, listening, speaking, and note-taking skills, adopt formal and legal language, and prepare for upcoming courses such as Note-Taking, Consecutive Interpreting, Translation of Texts on Law and International Affairs and European Union Studies and Translation. Moreover, as the students become active learners in this situated learning activity, they become aware of their metacognitive knowledge and use it in order to achieve deep learning.

Despite all these advantages, the present study was carried out with respect to second-year students. As for future attempts, we intend to make use of senior students in MUN simulations, specifically in Simultaneous Interpreting, Simultaneous Conference Interpreting, and Consecutive Interpreting courses. It is expected that further application of situated learning of this nature can provide the students with opportunities to comment on the present methodology so as to be used and applied to improve other related courses at the departmental level.

\section{References}

Adey, P., and Shayer, M. (1993). An exploration of long-term far-transfer effects following an extended intervention program in the high school science curriculum. Cognition and Instruction, 11(1), 1-29. $\begin{array}{lllll}\text { Retrieved on December } & 018 \text { from: }\end{array}$ https://www.tandfonline.com/doi/abs/10.1207/s1532690xci1101_1

Altındağ, M., Senemoğlu, N. (2013). Metacognitive skills scale. Hacettepe University Journal of Education, 28(1), 15-26.

Anderson, L. V., Krathwohl, D. R. (2001). A taxonomy for learning, teaching, and assessing: A revision of Bloom's taxonomy of educational objectives. New York: Pearson.

Calvo, E. (2015). Scaffolding translation skills through situated training approaches: Progressive and reflective methods. The Interpreter and Translator Trainer, 9(3), 306-322. DOI: 10.1080/1750399X.2015.1103107

Engel, S., Pallas, J., Lambert, S. (2017). Model united nations and deep learning: Theoretical and professional learning. Journal of Political Science Education, 13(2), 171-184. DOI: $10.1080 / 15512169.2016 .1250644$ 
Flavell, J. H. (1979). Metacognition and cognitive monitoring: A new area of cognitive developmental inquiry. American Psychologist, 34(10), 906-911.

Fortin, J. C. (2012). Role-playing and simulation based learning in higher education: Case study in model united nations. PhD dissertation. Bryant University. Retrieved on December 01, 2018 from: https://pdfs.semanticscholar.org/ee65/2f0f63ed5b0cfe0af4cb4ea76b2ecf790c8d.pdf

Hazleton, W. A., Mahurin, R. P. (1986). External simulations as teaching devises: The model united nations. Simulation \& Games, 17(2), 149-171.

Hendricks, C. C. (2001). Teaching causal reasoning through cognitive apprenticeship: What are results from situated learning?. The Journal of Educational Research, 94(5), 302-311. Retrieved on December 02, 2018 from: http://hibgroupbpr.pbworks.com/f/Situated\%2BCognition\%2BStudy.pdf

Kiraly, D. (2000). A social constructivist approach to translator education: Empowerment from theory to practice. Manchester: St. Jerome.

Kiraly, D. (2005). Project-based learning: A case for situated translation. Meta, 50(4), 1098-1111. Retrieved on December 01, 2018 from: https://www.researchgate.net/publication/271173631_Project-

Based_Learning_A_Case_for_Situated_Translation

Kuhn, D., Pearsall, S. (1998). Relations between metastrategic knowledge and strategic performance. Cognitive Development, 13, 227-247.

$\mathrm{Li}, \mathrm{X}$. (2015). Mock conference as a situated learning activity in interpreter training: A case study of its design and effect as perceived by trainee interpreters. The Interpreter and Translator Trainer, 9(3), 323-341. DOI: 10.1080/1750399X.2015.1100399

Prieto V., Antonio, J., Adrián, F. L. (2016). A collaborative multimodal working environment for the development of instrumental and professional competences of student translators: An innovative teaching experience. The Interpreter and Translator Trainer, 10(1), 76-91. DOI: 10.1080/1750399X.2016.1154344

Risku, H. (2002). Situatedness in translation studies. Cognitive Systems Research, 3, 523-533. DOI: 10.1016/S1389-0417(02)00055-4

Schraw, G. (1998). Promoting general metacognitive awareness. Instructional Science, 26, 113-125. DOI: $10.1023 / \mathrm{A}: 1003044231033$

Senemoğlu, N. (2007). Gelişim, ögrenme ve ögretim: Kuramdan uygulamaya [Development, learning and teaching: From theory to practice]. Ankara: Gönül Kitabevi.

Stein, D. (1998). Situated learning in adult education. ERIC Digest. Retrieved 03 December, 2018 from: http://www.ericdigests.org/1998-3/adult-education.html

Veenman, M. V. J., Wilhelm. P., Beishuizen, J. J. (2005). The relation between intellectual and metacognitive skills at the onset of metacognitive skill development. Instructional Science, 33, 193 211. Retrieved 03 December, 2018 from: https://pdfs.semanticscholar.org/324f/9c2c9a147cc122446e8df3614af9b861ef5e.pdf

Yanqun, Z. (2015). The concept and instruction of metacognition in translation competence development. International Forum of Teaching and Studies, 11(1-2), 69-78. DOI: $10.1080 / 13664530300200184$

Zull, J.E. (2011). From brain to mind: using neuroscience to guide change in education. Stylus Publishing: Sterling, VA. 


\section{Mütercim tercümanlik eğitiminde durumlu öğrenme: Model birleşmiș milletler}

\section{$\ddot{O} \mathbf{z}$}

Mütercim tercümanlık eğitiminde kuram ve uygulamanın bütünleşmesinin gerekliliği eğitimciler tarafından her zaman vurgulanmıştır. Durumlu öğrenme aktiviteleri öğrencilerin kuramı uygulamayla bütünleştirdiği ortamlar olarak kabul edilmektedir. Bu çalışmanın amacı, bir durumlu öğrenme ortamı olan Model Birleşmiş Milletler simülasyonunun mütercim tercümanlık lisans eğitiminde faydalı bir şekilde uygulanabildiğini ve bu simülasyonların özellikle üstbilişsel düzeyde öğrencilerin derin öğrenmeyi başarmasına katkıda bulunduğunu göstermektir. Veriler 2015-2016, 2016-2017 ve 2017-2018 bahar döneminde öğrencilerin eğitmen, ders ve kendi performanslarına ilişkin değerlendirme ve yorumlarda bulundukları öğrenme çıktıları anketleri ve öğrenci bilgi sistemi yoluyla doldurulan formlardan toplanmıştır. Veriler, her bahar döneminde tartışılmış olan konulara ve konuların terminolojilerine ilişkin iki kısa sınavın sonuçlarıyla güçlendirilmiştir. Sonuçlar, öğrencilerin Model Birleşmiş Milletler simülasyonlarına aktif bir şekilde katılımlarının meta-bilişsel gelişimlerine ve mesleki kariyerleri için gerekli olan bilgi ve becerileri edinmelerine büyük katkı sağladığını göstermektedir.

Anahtar sözcükler: çevirmen eğitimi; mütercim tercümanlık; durumlu öğrenme aktivitesi; derin öğrenme; Model Birleşmiş Milletler simülasyonu; çeviri eğitimi

\section{AUTHOR BIODATA}

Dr. Gökçen Hastürkoğlu is working as an Assistant Professor at the Faculty of Arts and Sciences, Department of Translation and Interpretation, Atılım University, Ankara, Turkey. After completing her undergraduate degree at Hacettepe University, Translation and Interpretation Department, she earned her MA in the field of English Language and Literature. She completed her PhD in the field of English Linguistics. Her research interests are translation pedagogy, cognitive linguistics, medical translation, literary translation, and translation criticism. 